\title{
The Analysis of Potato Farming Systems in Chencha, Ethiopia: Input, Output and Constraints
}

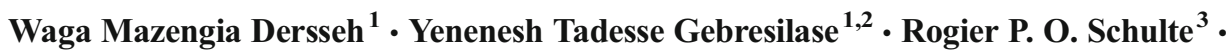 \\ Paul C. Struik ${ }^{1}$
}

Published online: 20 July 2016

(C) The Author(s) 2016. This article is published with open access at Springerlink.com

\begin{abstract}
A household survey was conducted for mixed farming systems in Chencha, Ethiopia. Goals of the survey were to establish a baseline for the current production system, to quantify the variation in input and output, and to identify constraints hindering expansion of potato production. Descriptive statistics and principal component analysis were computed using SPSS and XLSTAT. Input and product use constraints varied over household characteristics. Using improved varieties, inorganic fertilizers, and selling products strongly and positively correlated with the households' wealth, adoption, and education levels. Problems of cash and inadequate produce negatively correlated with wealth, adoption factors, and education levels. Access to improved varieties, training, and fertilizer were positively correlated with age, family size and gender. Land and labour shortages and pests were identified as cross-cutting constraints. Results of the analysis identify a need for a pluriform advisory model recognizing and building upon alleviation of the diversity of constraints identified in this analysis.
\end{abstract}

Resumen Se condujo una auscultación doméstica para sistemas mixtos de labranza en Chencha, Etiopía. Las metas de la encuesta fueron las de establecer una línea base para el

Waga Mazengia Dersseh

waga.dersseh@wur.nl; waga966@yahoo.com

1 Centre for Crop Systems Analysis, Wageningen University, P.O. Box 430, 6700 AK Wageningen, The Netherlands

2 Knowledge, Technology and Innovation Group, Wageningen University, Hollandseweg 1, 6700

EW Wageningen, The Netherlands

3 Crops, Environment and Land Use Programme, Teagasc, Johnstown Castle, Wexford, Ireland sistema de producción actual, para cuantificar la variación en insumos y producción, y para identificar restricciones que entorpecieran la expansión de la producción de papa. Se computaron estadísticas descriptivas y los análisis de los componentes principales, usando SPSS y XLSTAT. Las restricciones en los insumos y el uso del producto variaron sobre las características domésticas. El uso de variedades mejoradas, fertilizantes inorgánicos, y la venta de los productos, se correlacionaron fuerte y positivamente con la riqueza de los hogares, la adopción y los niveles de educación. Problemas de liquidez y la producción inadecuada se correlacionaron negativamente con la riqueza, factores de adopción y niveles de educación. El acceso a variedades mejoradas, entrenamiento, y la fertilización, estuvieron correlacionados positivamente con la edad, tamaño de la familia, y género. La tierra, la escasez de mano de obra y las plagas, se identificaron como limitantes transversales. Los resultados del análisis identifican la necesidad de un modelo de asesoría multiforme, reconociendo y construyendo sobre remediación de la diversidad de restricciones identificadas en este análisis.

Keywords Improved varieties $\cdot$ Inorganic fertilizer $\cdot$ Labour shortage $\cdot$ Training

\section{Introduction}

Potato (Solanum tuberosum L.) is the fourth most important food crop and the primary non-grain food commodity in the world. It has been cultivated in Ethiopia for over 150 years; currently it is grown in many parts of the country. In Ethiopia, its production area has reached 59,504 ha cultivated by over one million households in the main cropping season of 2011 (CSA 2012). There is a high potential to expand the 
cultivation area of the potato crop, as most arable land is in principle suitable for cropping with potato. Potato has multiple benefits for low income households and where land shortage is a constraint. The potato grows quickly, has a high yield, and contains more energy and protein per unit area when compared to a cereal crop. Therefore, it plays a vital role in ensuring food security, which is a major concern for the country. However, its national average productivity was about 8 tons $\mathrm{ha}^{-1}$ in the 2011 main cropping season, which was far below the productivity $\left(40 \mathrm{t} \mathrm{ha}^{-1}\right)$ of improved varieties achieved in research trials (APHRD 2009). The average productivity of potato in the production systems with local varieties in Chencha and Dita highlands (>2500 m above sea level) is only about $2.4 \mathrm{t} \mathrm{ha}^{-1}$ (Mesfin et al. 2014).

One of the major factors attributed to the low productivity of potato is access to improved varieties. The main constraints to accessing improved varieties are lack of availability of healthy seed tubers and poor seed tuber quality (Hirpa et al. 2010; Gebremedhin et al. 2008; Berga and G. Woldegiorgis 1994). Adoption of improved varieties is hindered by awareness of the availability and use of improved technologies (Hirpa et al. 2010), shortage of land (CSA 2011a) and the high prices of healthy seed tubers (Agajie et al. 2013). Thus, the majority of potato growers in the country use local cultivars and poor quality seed tubers. Out of the total land allotted to potato production, only $0.5 \%$ of the land was covered by improved varieties in the 2011 main season (CSA 2011a). The seed shortage can be more aggravated in remote potato growing areas, such as Chencha woreda, which are far from the major seed sources.

Productivity of potato is also affected by different bacterial, fungal and viral diseases. Late blight followed by bacterial wilt, potato leaf roll virus, and potato virus Y (PVY) are the most important of these (Baye and G. Woldegiorgis 2013). Virus diseases cause degeneration of planting materials and yield loss (Nascimento et al. 2003). According to SchulteGeldermann (2013), the high incidence of these diseases in Eastern Africa is due to lack of good seed system, inappropriate use of chemicals to control fungal diseases, lack of proper sanitation, crop rotation and varietal resistance, among other factors. Most farmers in Ethiopia do not use pesticides and only a quarter of the potato farms were sprayed in the 2011 main season (CSA 2011a).

Suboptimal agronomic practices - other than lack of crop protection - further depress yields (Baye and G. Woldegiorgis 2013). Due to limited access to training, most farmers use the same, traditional crop management practices for ware and seed potatoes. Potato has a high demand for soil nutrients; however, soil fertility has been declining due to erosion, continuous cropping and mining of nutrients. Only half of the potato farms in 2011 were fertilized with DAP (35\%), urea $(2 \%)$ and DAP and urea together $(14 \%)$, while the rest were treated with organic fertilizer only $(27 \%)$ or did not receive fertilizer at all (12\%) (CSA 2012). An increase in the price of fertilizer (Endale 2011; Abush et al. 2011), adverse climate and illiteracy (Daniel and Larson 2010) hinder fertilizer adoption in the country.

Generally, the above constraints are important in all potato production areas of the country, with little variation across locations. Chencha is one of the potato production areas of southern Ethiopia facing these typical constraints. These constraints should be resolved to increase the productivity of potato to its potential, thereby playing a role in improving the livelihoods of small holder farmers. These diverse constraints need diversified research and development solutions at the local level because of the large biophysical and socioeconomic variations across locations. Hence, the Chencha project was initiated with the overall objective to develop sustainable seed potato systems in Chencha.

This part of the study has three objectives: (1) to create a baseline of the general production system in the highland areas of Chencha, (2) to quantify the variation in household and farming types on a scale from 'closed', self-sufficient systems to 'open', commercial systems, and 3) to identify and rank constraints to improving potato yield as perceived by farmers and to relate these to farm/household type.

\section{Materials and Methods}

\section{Description of the Study Area}

Chencha is one of the districts of North Omo Zone of southern Ethiopia. The total area of the district is $373.5 \mathrm{~km}^{2}$ with a human population density of 388 persons per square kilometre (CSA 2011b). The altitude ranges from 2000 to $3000 \mathrm{~m}$ above sea level ( $\mathrm{m}$ asl). The agro-ecology is classified as highland ( $>2500 \mathrm{~m}$ asl), which accounts for $82 \%$ of the total area, and midland (2000-2500 $\mathrm{m}$ asl) accounting for $18 \%$. The minimum air temperature ranges from 11 to $13{ }^{\circ} \mathrm{C}$, whereas the maximum ranges from 18 to $24^{\circ} \mathrm{C}$. Based on 8 years $(2002$ 2009) data from the Office of Agriculture, the average annual rainfall is $1172 \mathrm{~mm}$ with a peak in April followed by a second peak in September. As a result of this bimodal rainfall pattern, there are two cropping seasons locally known as Belg (March to May) and Meher (June to October). The district has 45 administrative units which are locally known as kebeles (the smallest administrative unit, similar to a ward, which each consists of on average 395 households in the case of Chencha). While potato is produced in all these kebeles, 33 $(73 \%)$ earmarked as a potential prime production areas.

\section{Site and Farmer Selection}

Among the potential potato production kebeles, five kebeles were selected for the survey in consultation with experts of 
the district office of Agriculture, these were: Losha, Gendogembela, Yuera, Laka, and Tegecha. These kebeles were selected because, together, they represented the distribution of the agro-ecological condition of the 33 potential potato production kebeles. A total of 21 villages were randomly selected from all kebeles and each kebele was represented by at least two and at most six villages. Lists of names of farmers registered by each kebele administration were used to select every tenth farmer in the list. Care was taken to make sure that different household characteristics, mainly gender and wealth classes, were included although not proportionally. As a result, a total of 57 households were selected from the five kebeles, i.e. nine to fourteen households from each of the five kebeles. However, for the purpose of this paper, we considered only the data from 47 households of the first four kebeles, which represent the highland agro-ecology that covers the largest part of the district with similar cropping systems.

\section{Data Collection}

A questionnaire was used to collect the data, employing individual interviews with household heads. Whenever necessary, open-ended questions were also used for clarification. The interviews were conducted from October to November 2012. The data collected included household characteristics and practices related to overall crop and livestock farming as well as use of inputs and outputs (input/output) and constraints specific to potato production. The household characteristics collected were gender of the household head, wealth status based on local classification (poor, medium and rich), age of the household head, education level of the household head (uneducated, elementary school level [Grade 2 to 6], junior school level [Grade 7 to 8], senior or high school level [Grade 9 to 12]), family size and potato technology adoption level of a household (adopter or non-adopter). Adoption of potato technology refers to adoption of one or more of the improved potato technologies: improved variety (high yielding and resistant to diseases), row planting (at spacing of $75 \mathrm{~cm}$ by $30 \mathrm{~cm})$, fertilizer use $\left(195 \mathrm{~kg}\right.$ DAP ha ${ }^{-1} \& 165 \mathrm{~kg}$ Urea $\mathrm{ha}^{-1}$ ), crop rotation ( $\geq 3$ years break), triple cultivation and earthing up, pesticide and diffused light storage. Wealth status and adoption level of households were determined by the local administrators together with Development Agents of the Office of Agriculture. The criteria used to determine the wealth status of participating households were: (1) type and number of houses; (2) number of cattle and horses; (3) size of land holding; (4) age of owned enset plants; and (5) number of bamboo and eucalyptus trees. The input/output management practices specific to potato were use of inorganic fertilizer (DAP and/or urea), improved variety, hiring-in labour, access to training, and sale of surplus potato produce. Data were also taken on the practice of off-farm income generation.

\section{Data Analysis}

Descriptive statistics (frequency, percentage, mean standard deviation and cross tabulation) were computed on most of the data using SPSS version 20. Pearson Chi-square was used to test significance. The degree of 'openness' of farms vis-àvis input/output was evaluated by accounting for the total number of inputs/outputs practised per household. Principal component (PC) analysis was computed to derive the degree of association of household characteristics to input/output and production constraints using XLSTAT 2014. Class intervals were used to analyse descriptive statistics for age, education level and family size, whereas their actual values were used to compute PC analysis.

\section{Results}

\section{Baseline of Production System}

\section{Households' Characteristics}

Most of the sample households $(n=47)$ were headed by men (Fig. 1). The ages of the household heads varied from young to old with an average of about 44 years. The average family size was nearly seven persons per household. Based on the local classification, most of the sample households were of medium wealth status and the proportion of poor and rich households were nearly equal. Most of the households had land holding less than one ha with an average of about 1.4 ha per household. The variation in farm size was associated with the wealth status of households. Generally, the farm of a household was fragmented over different locations. The majority of the households were adopters of at least one improved potato technology. Most of the household heads were not educated while others had attended schools at a range of levels (Fig. 2).

\section{Crop Production}

Different crops were grown in two cropping seasons, which receive different amounts of rainfall. Common crops included cereals, pulses, root and tuber crops, vegetables, fruit crops and oil crops. On average, about nine crops (range: 5-13) were grown per household. The most widely cultivated crops were enset (Enset ventricosum [Welw.] Cheesman), barley (Hordeum vulgare L.), potato (Solanum tuberosum L.), wheat (Triticum aestivum L.), kale (Brassica oleracea L.), faba bean (Vicia faba L.) and apple (Malus domestica Borkh.). The former four crops were grown by all households. Improved varieties were used for production of mainly potato and wheat and in a few cases for barley whereas local varieties were used for the other crops. Sole cropping and double cropping 


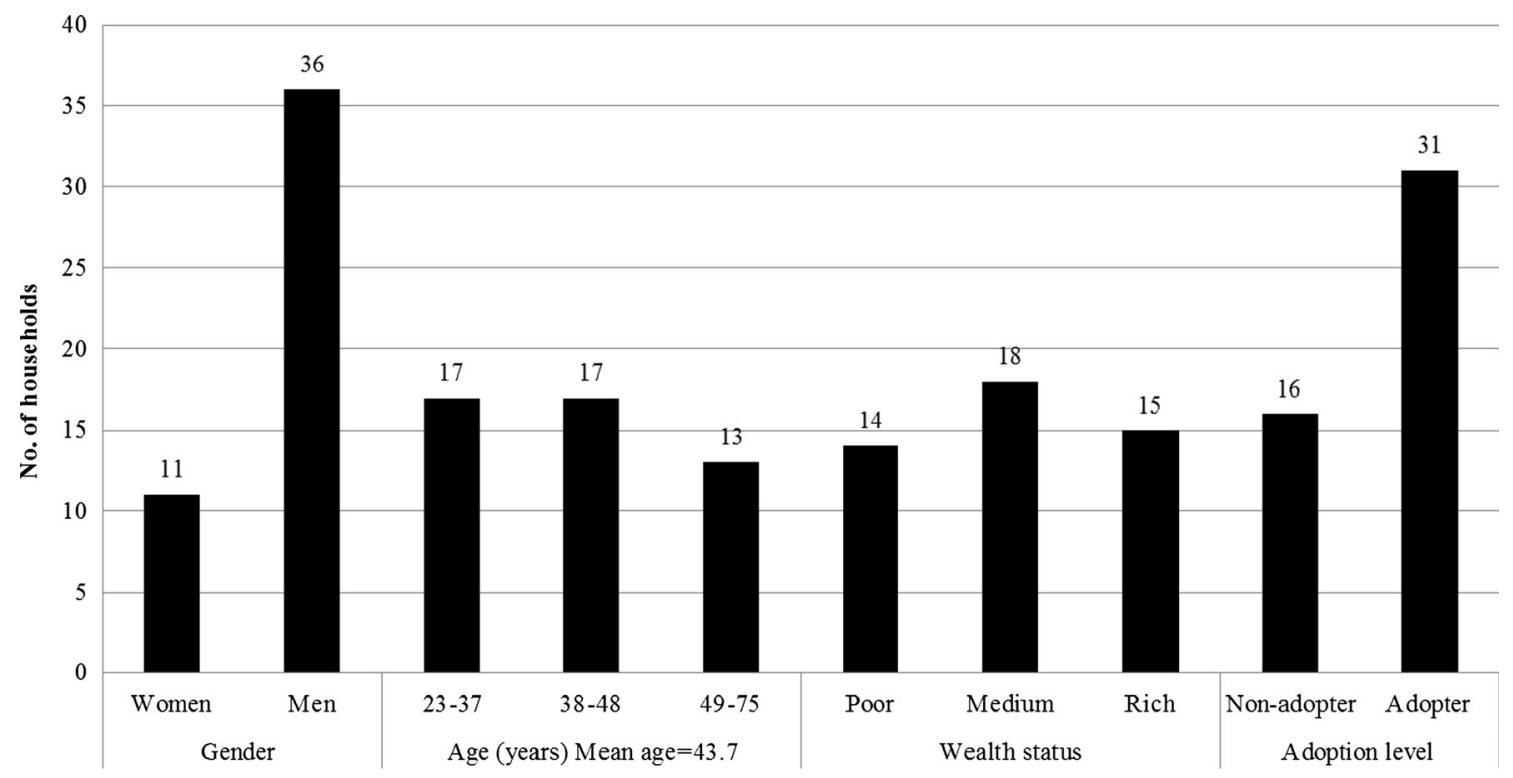

Fig. 1 Number of sample households against gender, age, wealth status and potato technology adoption levels

(growing two crops on the same land in a year) were commonly practised in the area. The most common crops grown in the Belg season were potato and barley which could also be grown in Meher season, along with other annual crops.

Land preparation was implemented largely by hand, as were other farm operations. An ox ploughing was also used by some households. For potato production, hand and oxen ploughing was practised by 83 and $17 \%$ of households, respectively. The majority (77\%) of farmers used triple ploughing for potato. Potato fields were commonly weeded three times whereas wheat and barley fields were weeded once.

Inorganic and organic fertilizers were commonly used in the area. For potato production, the majority $(57 \%)$ of the households used inorganic fertilizers only, whereas 17 and $26 \%$ of the households used only organic fertilizers or a combination of both types of fertilizers, respectively. The common inorganic fertilizers were DAP and Urea, which were used by about 76 and $73 \%$ of the households, respectively, irrespective of crop type. The most widely used organic fertilizer was farmyard manure, while compost was used by a few households.

The average amount of potato produced per household was $5.8 \mathrm{t}$ (range: 0.3 to 28.5 ) per year. Disaggregating the data by wealth class, the average amount produced by poor, medium and rich households was 2.3, 4.4 and $10.7 \mathrm{t}$, respectively. Nonadopters produced $1.7 \mathrm{t}$, while adopters produced $7.9 \mathrm{t}$. The amount of potato produced per household was significantly

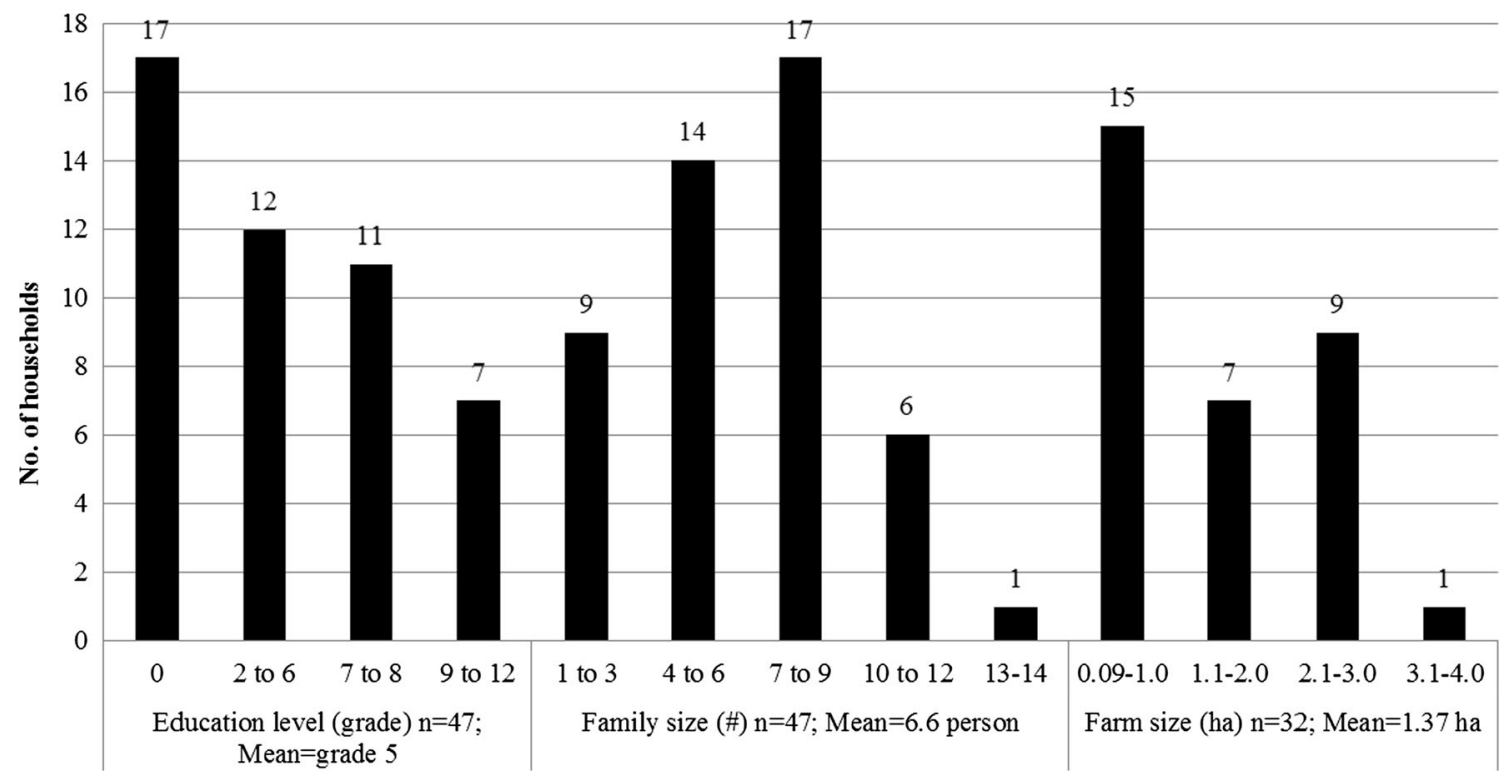

Fig. 2 Number of households against education level of the household head, family and farm size 
$(p<0.01)$ correlated $(r=0.61)$ with the farm size of the households. Most of the households sold their produces to local market as ware and/or seed and the number of households which sold potato produce varied over household characteristics (Table 1). Generally, the amounts of potato sold as seed $(r=0.90)$ and ware $(r=0.72)$ were significantly $(p<0.01)$ correlated with the amount of produce per household.

\section{Livestock Production}

The main livestock types reared in the highlands of Chencha were cattle, sheep, chicken and horses, which were reared by about $98,75,38$, and $26 \%$ of the households, respectively. Rich households had relatively more of all of the above animals, while horses were kept only by medium and rich households. Generally, the number of animals decreased from year to year, mainly due to feed shortage and disease. The most common animal feed types were enset leaves, weeds, crop residues and grasses from private pasture. Croplands were generally grazed by the livestock after harvest. Based on farmers' ranking, enset leaves were the primary fodder source for rich and medium households, whereas weeds were the major source for poor households. Private pasture (natural grass grown on private land) was an important feed source for rich households. Communal grazing areas are grazed by livestock, which are attended by all members of a family, but particularly by children.

\section{Income Sources}

Farmers usually received their income from both on-farm and off-farm sources. Common on-farm sources were crop and livestock products. The off-farm sources included weaving, small trading, hiring out labour and remittances. Based on farmers' overall ranking, crop products were the most important income source followed by weaving and small trading. For poor male headed households, hiring out labour was an important source of income, whereas remittance was an income source only for female headed households, mainly from their children and spouses. In general, on-farm income sources were more important for most households than off-farm income sources. On-farm income sources were specifically important to rich and medium households whereas off-farm income sources were important to poor ones.

\section{Degree of Openness of Potato Farms to Input and Output}

\section{Total Number of Inputs and Outputs per Household}

The inputs considered were improved variety, inorganic fertilizer, training, hiring-in labour, income from off-farm source and sale of potato produce. Most households used four inputs, but this number was significantly influenced by wealth status and adoption level of the households (Table 2). The average number of inputs/outputs used by the rich households was twice that of the average used by poor households. Similarly, the mean number of inputs/outputs used by adopter households was much higher than that used by non-adopter households.

\section{Degree of Association Between Input/Output use and Household Characteristics}

Principal component analysis on input/output use and household characteristics showed that the first three principal components (PCs) have eigenvalues greater than one and they explained about $61 \%$ of the total variance while each of them contributed about 33, 14 and $14 \%$, respectively. The first principal component (PC1) was strongly and positively correlated with seven of the ten original variables having correlation coefficient values of $\geq 0.65$. However, $\mathrm{PC} 1$ correlated most with wealth status, adoption level, use of inorganic fertilizer, improved variety and selling of products with similar loadings suggesting that $\mathrm{PC} 1$ was characterized primarily by these variables. The association among these variables is easily depicted in the loading plot (Fig. 3a). The second principal component (PC2) was loaded by large negative values of gender and large positive values of hiring-in labour and they are located on the opposite sides in Fig. 3a. Bi-plot of PC1 versus PC2 showed that households or farms were not clustered among themselves and to practices of certain input/output and household characteristics (Fig. 3b).

\section{General Constraints of Potato Production}

Principal component analysis related to production constraints revealed that the first seven principal components had eigenvalues greater than one and they explained about $73 \%$ of the total variance. However, the first three PCs accounted for about $44 \%$ of the total variation. PC1 was characterized by relatively large positive values of wealth status, adoption and education levels and market constraints. Figure 3a clearly shows this strong and close mutual association. PC1 was also characterized by large negative value of cash shortage. Cash problem and insufficient quantities of produce were positively correlated and both were negatively correlated with wealth, adoption and education levels in PC1. In PC2, constraints of access to improved varieties and training and to some extent fertilizer were positively correlated mainly with age and family size and to some extent with gender. Pest, land shortage and labour shortage were cross-cutting constraints for all households (Fig. 4a). The distribution of farms over PC1 and $\mathrm{PC} 2$ showed that there was no clear clustering of farmers and few farms were outliers in both PC1 and PC2 (Fig. 4b). 
Table 1 Number of households which sold their potato as seed and ware against household characteristics

\begin{tabular}{|c|c|c|c|c|c|c|c|}
\hline \multicolumn{2}{|c|}{ Household characteristics } & \multicolumn{6}{|c|}{ Number of households } \\
\hline & & \multicolumn{2}{|c|}{ As seed and/or ware } & \multicolumn{2}{|c|}{ As seed } & \multicolumn{2}{|c|}{ As ware } \\
\hline & & No & Yes & No & Yes & No & Yes \\
\hline \multirow[t]{2}{*}{ Gender } & Female $(n=11)$ & 6 & 5 & 6 & 5 & 9 & 2 \\
\hline & Male $(n=36)$ & 10 & 26 & 16 & 20 & 13 & 23 \\
\hline \multirow[t]{3}{*}{ Wealth } & Poor $(n=14)$ & 9 & 5 & 10 & 4 & 9 & 5 \\
\hline & Medium $(n=18)$ & 5 & 13 & 9 & 9 & 7 & 11 \\
\hline & Rich $(n=15)$ & 2 & 13 & 3 & 12 & 6 & 9 \\
\hline \multirow[t]{3}{*}{ Adoption level } & Non-adopter $(n=16)$ & 11 & 5 & 14 & 2 & 11 & 5 \\
\hline & Adopter $(n=31)$ & 5 & 26 & 8 & 23 & 11 & 20 \\
\hline & General $(n=47)$ & 16 & 31 & 22 & 25 & 22 & 25 \\
\hline
\end{tabular}

\section{Discussion}

The farming system of the study area was a mixed farming system where crops and livestock husbandry occurred simultaneously. Similar farming systems are practised by the majority ( $82 \%)$ of rural households in the country (CSA and World Bank 2013). Highland areas of southern Ethiopia with farming systems similar to the ones in Chencha include highlands of Gamo Gofa, Bule, Hagereselam, Geta, Gumer and
Duna. Diverse crops and livestock are grown in these areas with predominantly traditional management practices. These areas are also characterized by a high population pressure resulting in land shortage.

\section{Hierarchy of Constraints}

The multiple constraints facing the smallholder farmers can be categorised into a hierarchical order, shown in Fig. 5. The first

Table 2 Percentage of households within household characteristics against number of inputs/outputs used per household

\begin{tabular}{|c|c|c|c|c|c|c|c|c|c|c|c|c|}
\hline \multicolumn{2}{|c|}{ Household characteristics } & \multirow[t]{2}{*}{ Total N } & \multicolumn{7}{|c|}{ Number of input/output used per household } & \multirow[t]{2}{*}{ Pearson Chi- square } & \multirow[t]{2}{*}{ Mean \# of input } & \multirow[t]{2}{*}{$\mathrm{SD} * 1$} \\
\hline & & & 0 & 1 & 2 & 3 & 4 & 5 & 6 & & & \\
\hline \multirow[t]{2}{*}{ Gender } & Female & 11 & 0 & 9 & 9 & 27 & 27 & 9 & 18 & \multirow[t]{2}{*}{$3.5(p=0.745)$} & 3.73 & 1.6 \\
\hline & Male & 36 & 3 & 3 & 11 & 17 & 33 & 25 & 8 & & 3.83 & 1.4 \\
\hline \multirow[t]{3}{*}{ Wealth } & Poor & 14 & 7 & 14 & 36 & 21 & 7 & 14 & 0 & \multirow[t]{3}{*}{$40.4\left(p<0.000^{* * *}\right)$} & 2.50 & 1.4 \\
\hline & Medium & 18 & 0 & 0 & 0 & 33 & 50 & 17 & 0 & & 3.83 & 0.7 \\
\hline & Rich & 15 & 0 & 0 & 0 & 0 & 33 & 33 & 33 & & 5.00 & 0.8 \\
\hline \multirow[t]{3}{*}{ Age (years) } & $22-37$ & 17 & 6 & 0 & 18 & 18 & 24 & 12 & 24 & \multirow[t]{3}{*}{$19.0(p=0.088)$} & 3.82 & 1.7 \\
\hline & $38-48$ & 17 & 0 & 0 & 6 & 18 & 29 & 41 & 6 & & 4.24 & 1.0 \\
\hline & $49-75$ & 13 & 0 & 15 & 8 & 23 & 46 & 8 & 0 & & 3.23 & 1.2 \\
\hline \multirow[t]{4}{*}{ Education level } & Uneducated & 17 & 6 & 12 & 18 & 29 & 24 & 6 & 6 & \multirow[t]{4}{*}{$19.1(p=0.381)$} & 2.94 & 1.5 \\
\hline & Elementary & 12 & 0 & 0 & 8 & 25 & 25 & 33 & 8 & & 4.08 & 1.2 \\
\hline & Junior & 11 & 0 & 0 & 9 & 9 & 27 & 36 & 18 & & 4.45 & 1.2 \\
\hline & Senior & 7 & 0 & 0 & 0 & 0 & 71 & 14 & 14 & & 4.43 & 0.8 \\
\hline \multirow[t]{5}{*}{ Household size } & $1-3$ & 9 & 0 & 22 & 11 & 11 & 33 & 11 & 11 & \multirow[t]{5}{*}{$21.1(p=0.628)$} & 3.33 & 1.7 \\
\hline & $4-6$ & 14 & 7 & 0 & 7 & 21 & 29 & 29 & 7 & & 3.79 & 1.5 \\
\hline & $7-9$ & 17 & 0 & 0 & 18 & 12 & 29 & 24 & 18 & & 4.12 & 1.4 \\
\hline & $10-12$ & 6 & 0 & 0 & 0 & 33 & 50 & 17 & 0 & & 3.83 & 0.8 \\
\hline & $13-14$ & 1 & 0 & 0 & 0 & 100 & 0 & 0 & 0 & & 3.00 & . \\
\hline \multirow[t]{2}{*}{ Adoption level } & Non-Adopter & 16 & 6 & 13 & 25 & 31 & 13 & 13 & 0 & \multirow[t]{2}{*}{$18.7\left(p<0.005^{* *}\right)$} & 2.69 & 1.4 \\
\hline & Adopter & 31 & 0 & 0 & 3 & 13 & 42 & 26 & 16 & & 4.39 & 1.0 \\
\hline \multirow[t]{2}{*}{ Total households } & $\mathrm{N}$ & 47 & 1 & 2 & 5 & 9 & 15 & 10 & 5 & & & \\
\hline & $\%$ & 100 & 2.1 & 4.3 & 10.6 & 19.1 & 31.9 & 21.3 & 10.6 & & & \\
\hline
\end{tabular}

$* *$ Significant at $p<0.01 ; * * *$ Significant at $p<0.001 ; *{ }^{1}$ Standard deviation 
Fig. 3 a Loading plot showing the relationship among individual input use and household characteristics over two principal components. PC1 refers to the left and right sides of $\mathrm{X}$-axis whereas PC2 refers to the upper and bottom sides of Y-axis. b Bi-plots showing the association of farms with individual input use and household characteristics. PC1 refers to the left and right sides of $\mathrm{X}$-axis whereas $\mathrm{PC} 2$ refers to the upper and bottom of Y-axis a

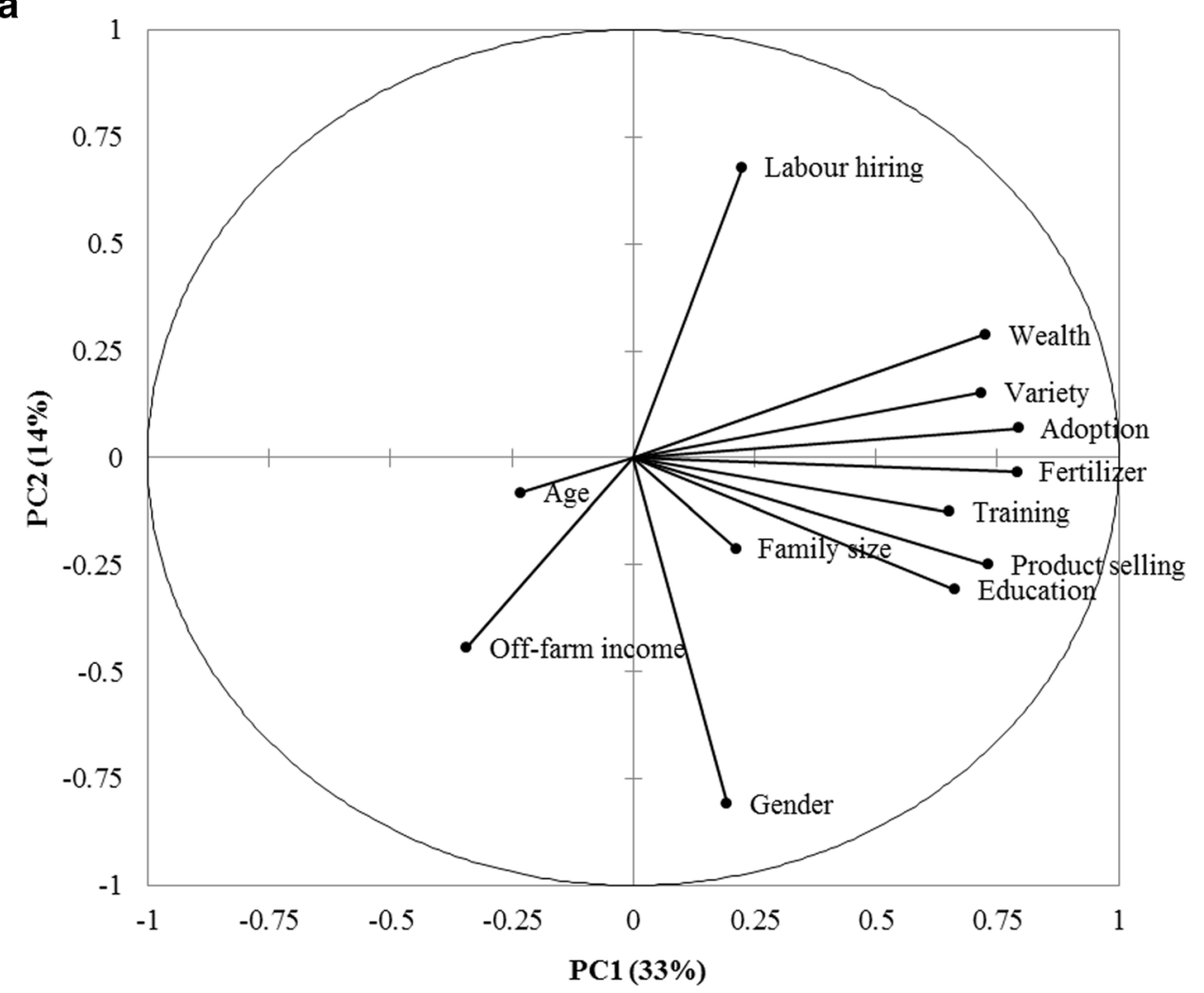

b

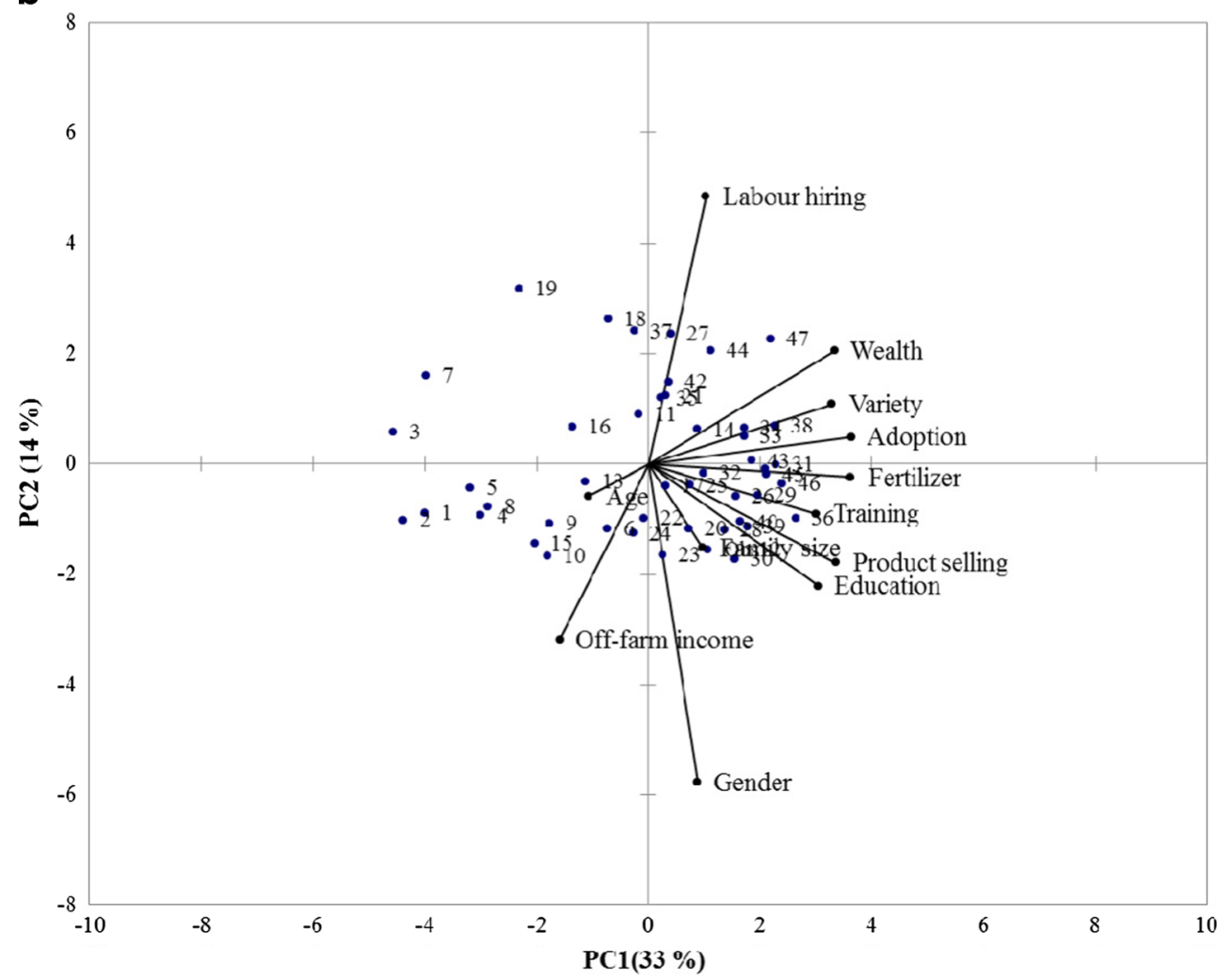

constraint relates to the limited availability of land, which is a base for crop production without which any of the other constraints are irrelevant. Subsequently, for farmers who have overcome this constraint, resolving cash shortages emerges as 
Fig. 4 a Association among constraints and household characteristics over two principal components. PC1 refers to the left and right sides of $\mathrm{X}$-axis wheres PC2 refers to the upper and bottom sides of Y-axis. $\mathbf{b}$

Distribution of farms in relation to contraints and household characteristics over two principal components. PC1 refers to the left and right sides of $\mathrm{X}$-axis whereas PC2 refers to the upper and bottom sides of Y-axis a

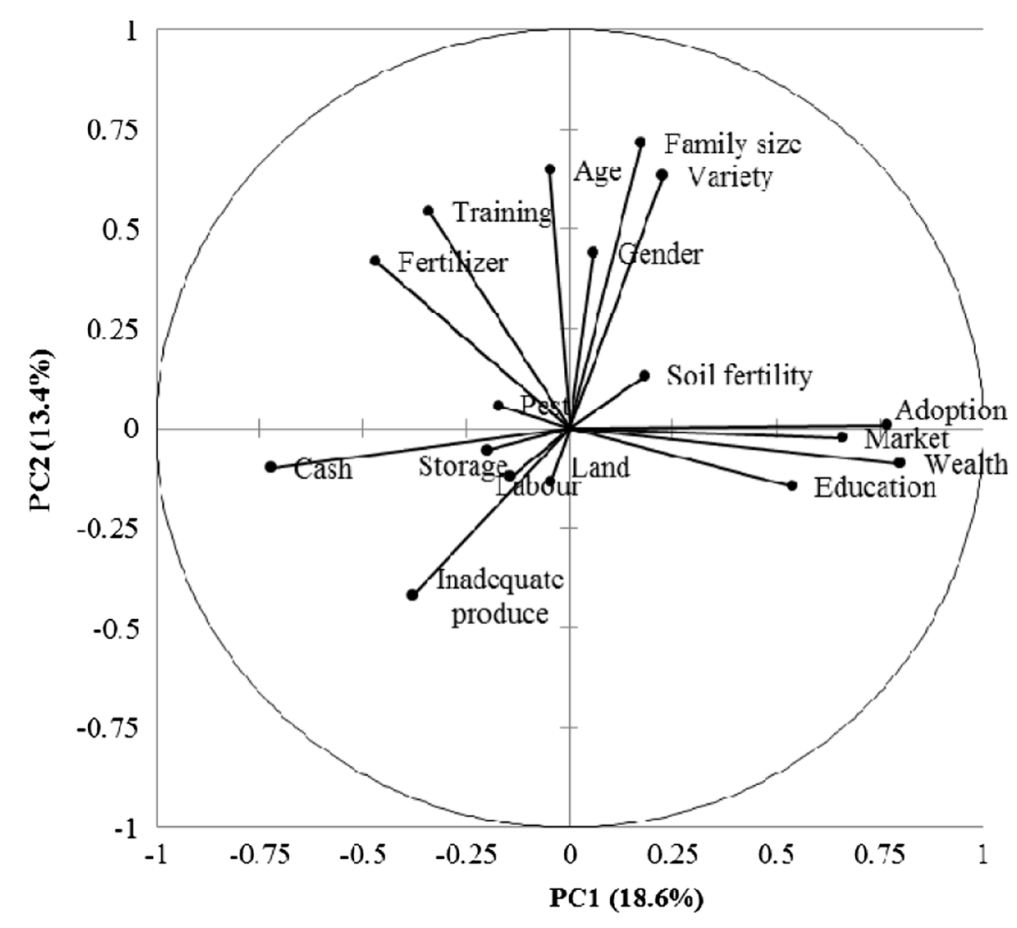

b

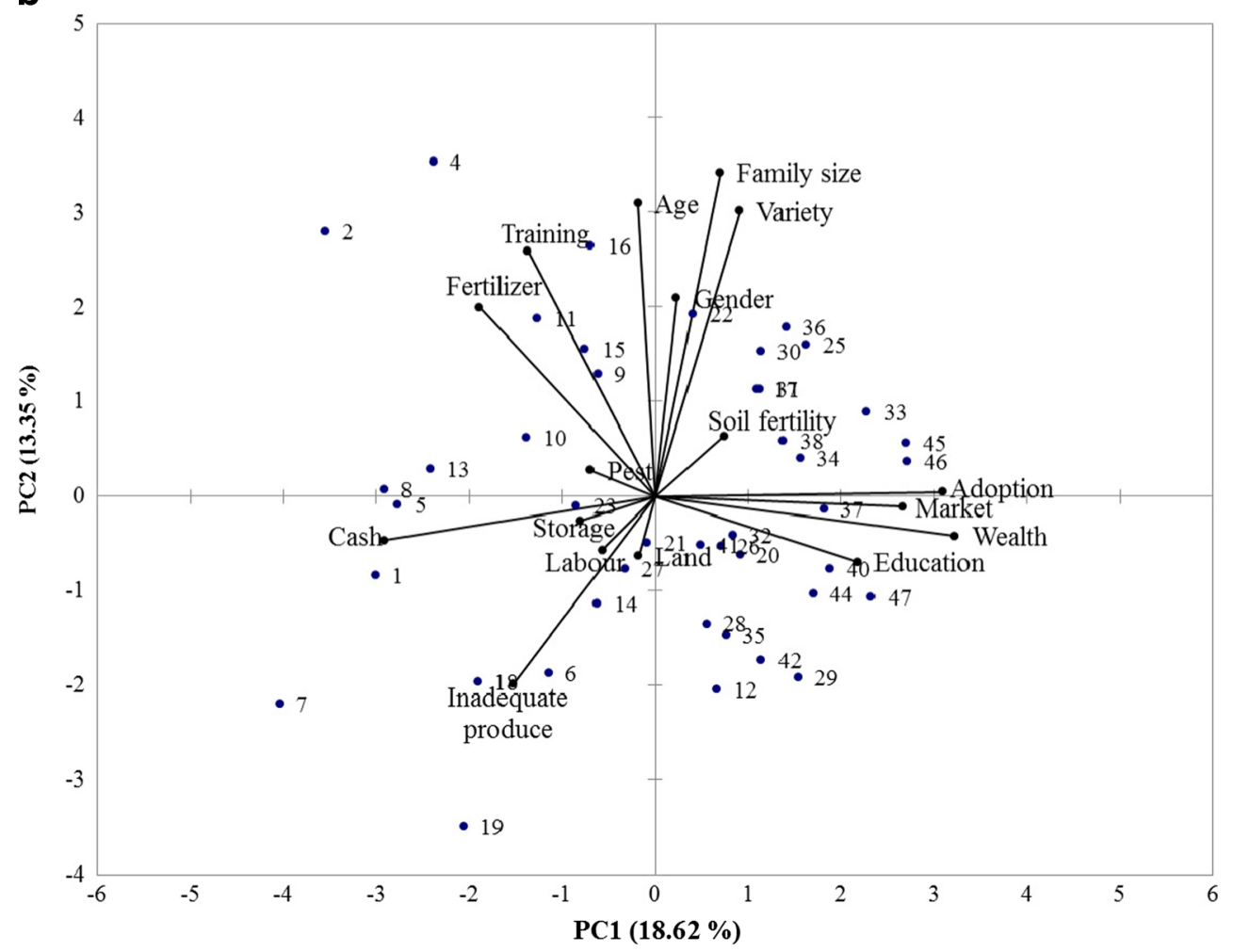

the next constraint, as cash is a primary input to obtain essential inputs for production. Then labour shortage should be alleviated as most of the farm operations use human labour. For farmers who have land, cash and labour available, access to training becomes a relevant constraint to effectively planning and using the available inputs. Trained farmers can further improve productivity by using improved varieties, using quality seeds. Once productive crops are grown, pest control measures are required. If these conditions are fulfilled, it is likely that farmers harvest enough produce to sell: only for 


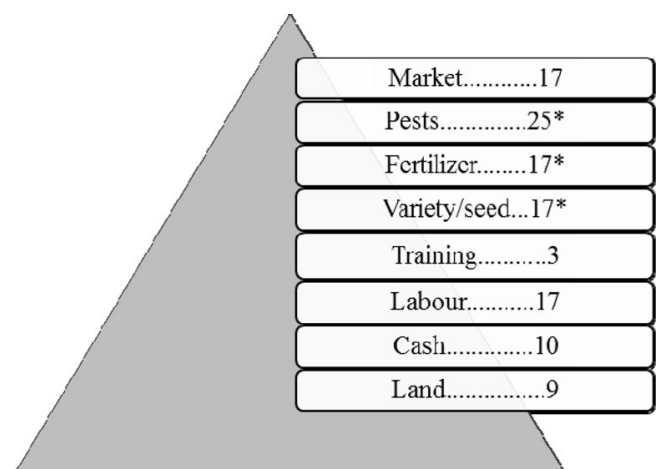

Fig. 5 Hierarchical order of contraints from bottom to top and number of households constrained $(* N=47$ for others $N=43$ )

these farmers, access to market becomes the main constraint. The following discussion section follows this hierarchical order in Fig. 5 from bottom to top. The hierarchy does not match with the number of households identifying the constraints because farmers' responses were on the degree of importance of constraints but not on their hierarchical order.

\section{Land Availability}

Land shortage was a cross-cutting constraint raised by some of the interviewed households. Farmers specifically associated land shortage to the large amount of land required to meet the recommended rotation ( $\geq 3$-years) of potatoes. Land shortage is a common constraint in the high population density areas of the country (Josephson et al. 2014). It is one of the constraints that hinder the full implementation of the extension packages for other crops, too (CSA 2011a). The size of land holding positively influences the adoption of potato technologies (Beliyu et al. 2013). To solve their general land problems, some farmers in the study area hire land from other farmers who experience a shortage of inputs (cash, labour, seed and fertilizer) and/or whose fields are too far away to manage effectively by themselves.

\section{Cash Availability}

The strong negative association of cash shortage with wealth, adoption and education level in PC1 (Fig. 4a) indicates that cash shortage is a main constraint to poor, non-adopter and uneducated households. Most of the non-adopter (71 \%) and uneducated (57\%) households were poor and cash shortage was mainly associated to their inability to purchase inorganic fertilizer and labour. Moreover, the positive correlation between cash shortage and inadequate produce in PC1 (Fig. 4a) indicates a vicious poverty cycle where lack of cash results in inadequate productivity and vice versa. Shortage of cash is the most important reason why farmers in Ethiopia do not implement the extension packages for different crops (CSA Central Statistics Agency 2011a). At national level, the potato extension package was fully implemented on only $15 \%$ of the potato farm area during the 2011 main season. Most farmers do not use financial credits for two reasons: (1) because they expect that they will not be able to pay off loans and (2) because of the unavailability of credit services.

\section{Labour Availability}

Labour is a cross-cutting constraint associated with the high labour requirement of potato production. The opposite relationship between practices of hiring-in labour and off-farm income generation in PC1 (Fig. 3a) indicates that households that were engaged in off-farm activities had little experience with hiring-in labour and vice versa. This may be related to the household's capacity to hire-in labour, as most (86\%) of the households which were engaged in off-farm income activities were poor, whereas most of those which relied on hired-in labour were rich. This contradicts findings by Belete (2006), who found that most households which are engaged in weaving prefer to hire-in labour for agricultural activities so that they have sufficient time for weaving. In our results, the large negative correlation values of gender and positive values of hiring-in labour in PC2 (Fig. 3a) implies that hiring labour was more dependent on the gender of the household head. Accordingly, most of female-headed households had more experience with hiring-in labour, compared to the maleheaded households and this may be attached to the local tradition that tillage is the responsibility of men (Belete 2006). The cost of labour, which includes the daily meals of the laborer, is increasing over time and is becoming unaffordable for most of the households.

\section{Access to Training}

The positive association of reduced access to training with age, family size and gender in PC2 (Fig. 4a) suggests that access to training was related to age, larger family sizes and male-headed households. The reason why none of the female headed households considered lack of access to training to be a constraint may be due to lack of awarenes on its importance. Some farmers in the country do not get adequate advisory service (Bezabih and Nigussie 2011) and lack of awareness about the availability and use of improved technologies and management practices has hampered adoption of potato technologies (Hirpa et al. 2010). Conversely, access to training positively influences the adoption of potato technologies (Beliyu et al. 2013).

\section{Use of Improved Varieties}

The use of improved varieties was predominantly governed by the households' wealth, adoption and education levels (PC1 in Fig. 3a). This is consistent with other research from 
Ethiopia that has shown that education level and access to extension service significantly influence the adoption of improved potato varieties (Gumataw et al. 2013; Teklemariam 2014; Beliyu et al. 2013). Wealthy households have better opportunities to access education; in turn educated farmers have better opportunities to access training on new technologies.

On the other hand, lack of access to improved varieties was related to age, larger family sizes and male-headed households (PC2 in Fig. 4a) and applied to all improved varieties including the most recently released ones which are more productive and resistant to diseases (e.g. late blight). Male farmers (particularly the rich ones and the adopters) who already had access to different improved varieties and training considered access to the most recently released varieties a constraint, because they were aware of such varieites. However, female-headed and poor households who had no information on the importance and presence of the recent varieties had interest in accessing any improved variety. Schulte-Geldermann (2013) noted that lack of demand for seeds of new varieties may be the result of inadequate information about their advanatages; thus awareness is an important element in the adoption of new varieties. This constraint of limited access to varieties in the study area is indicative of other parts of the country (Tewodros et al. 2014) which explains why improved varieties were used on only $0.5 \%$ of the potato cropping area in 2011 (CSA 2011a).

\section{Fertilizer Use}

Inorganic fertilizer use was largely influenced by the households' wealth, adoption and education levels (PC1 in Fig. 3a). Inorganic fertilizers were used mostly by wealthy, educated and adopter households. Wealthy households have the financial capacity to buy fertilizers and have better access to education which improves their awareness of the importance of fertilizers. This is consistent with other studies in Ethiopia that have shown that fertilizer adoption is positively influenced by education levels of the household heads (Endale 2011; CSA 2011a). Many poor households identified inadequate access to inorganic fertilizers a constraint, citing high prices and cash shortages, whereas timely delivery of fertilizer was a more prominent constraint for wealthy households. This shows that poor households may not adopt fertilizers due to their low financial capacity. Indeed, an increase in the price of fertilizer (Endale 2011; Abush et al. 2011) and adverse climate and illiteracy (Daniel and Larson 2010) have been a main constraint of fertilizer adoption in the country. Moreover, some farmers in the country cannot purchase available fertilizers, due to the large pack size (IFDC 2012).

\section{Pests}

The presence of pests was a cross-cutting constraint for all households. Pests included diseases, arthropods (millipedes) and vertebrates. The major potato diseases were late blight and bacterial wilt, whereas the major arthropod pests were millipedes. Vertebrate pests were porcupine, monkeys and mole rats which were more prevalent on farms in the vicinity of shrub vegetation. Most of the farmers do not know the causes or preventive and control measures of diseases; this may be due to lack of awareness as a result of limited training services. Bacterial wilt is a relatively recent phenomenon and needs special attention to prevent its expansion. Pesticides are not locally available and seeds of resistant varieties are not easily accessible.

\section{Product Use and Access to Market}

The practice of selling surplus produce was largely confined to rich, well-educated and adopter households. This demography cited inadequate access to market as their main constraint (PC1 in Fig. 4a). All of the farmers in the area harvest their potato nearly at the same time and immediately sell the produce in the nearby local markets at lower prices as a result of temporary oversupply. Farmers have a low capacity to access markets outside their vicinity to sell their produce at a better price. Moreover, most of them have a low financial and technical capacity to construct improved storage to store and sell their produce when prices improve. Low prices of ware potato was also reported as a constraint in Oromiya and Amhara regions (Agajie et al. 2013).

Box 1 shows a summary of the main potato production constraints and their linkage to main target households more affected by these constraints.

We found in our study that there are three drivers of constraints which are related to: (1) access to inputs for willing producers most of whom are self-sufficient; (2) poverty trap for the poorest and uneducated households whose farms are closed to most of the inputs and are characterised by a critical shortage of cash and produce for consumption; (3) market access for proficient producers whose farms are open to most of the inputs and have surplus produce. Therefore, there is a need to have pluriform advisory model, which recognises and builds on alleviating the diversity of constraints in the highland areas of Chencha. These findings have implications for the optimisation of extension services to farmers. The current extension service in Chencha is inclined towards a certain portion of the farming community. Fertilizers are supplied through direct purchase, limiting their availability to farmers who have sufficient financial means. Seeds of improved varieties accompanied by training are usually supplied to wealthy farmers who have sufficient resources to grow these varieties and to educated farmers who are expected to easily understand trainings. In addition, the formal extension systems (FES) prioritize specific cereal and pulse crops because the seeds of these crops are easily transportable and produced in relatively larger quantities compared to tuber crops. However, the FES 
Box 1 Linkage between production constraints and target households from two principal components

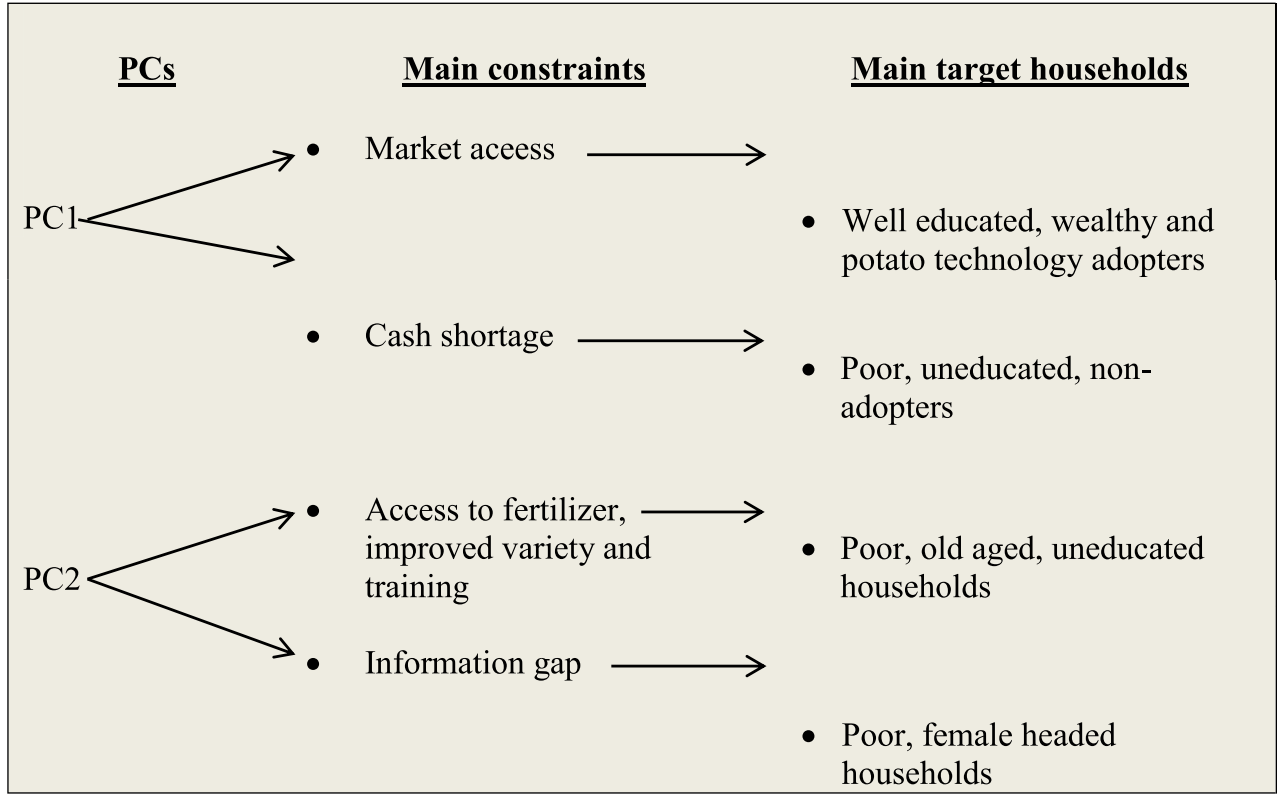

do not put enough effort into using the opportunity of producing tuber crops at local level without the support of nongovernmental organizations (NGOs), nor they have aimed to address land and labour shortages. Moreover, FES have focused exclusively on primary production and do not include training on the post-harvest handling and the marketing aspect of the products, which is a concern of mainly of the wealthier farmers. As our study shows that constraints differ over household characteristics, the following suggestions may contribute to developing a more pluriform extension service:

- Additional income generation activities that require less land and labour, such as bee keeping, could be promoted where farmers are constrained by land and cash shortages.

- The Chencha Office of Agriculture (COoA) in collaboration with NGOs should facilitate the introduction of recently released disease (late blight) resistant varieties and scale out local level seed tubers production to address the needs of different social categories. In-kind seed credit, which is being implemented by local development projects (such as the Vita project), should be promoted to equitably address the constraints of the poor households too.

- The Chencha Office of Agriculture and Cooperatives could facilitate timely delivery of fertilizers. In addition, the COoA and microfinance institutes could facilitate access to credit. Some farmers are not sure whether they can produce enough to repay their loans; they require training on how to maximise the effectiveness of their production systems.

- Cooperatives could facilitate better access to markets. The COoA, in collaboration with NGOs, could promote improved storages for ware potato to reduce post-harvest losses and to enable long-term storage to avail of better prices and increased consumption.

\section{Conclusions}

In this study, we uncovered the variations of input use in relation to household characteristics and identified important bottlenecks for potato production in the highlands of Chencha. The main constraints were related to access to inputs for willing producers, to the poverty trap for the poorest and uneducated households and to market access for proficient producers. Therefore, there is a need to develop a pluriform advisory model, which recognises and builds on alleviating the diversity of constraints faced by farmers from contrasting demographies. The following suggestions need be given due emphasis:

- The promotion of additional income generation activities that require less land and labour,

- The introduction of recently released disease resistant varieties and scale out local level seed production activities;

- Facilitation of the timely delivery of fertilizers and access to credit;

- Improving access to market and promoting improved storage facilities for ware potatoes;

- The limitation of the current study is the small sample size. Thus, validation of the findings is necessary, and

- Similar studies may be required for the midland part of Chencha, which has a different agro-ecology and cropping system. 
Acknowledgments We would like to thank Cathal Buckley and Cesar Ospina, for their contribution in the data analysis. This work was supported by the Wageningen University and Research Centre, Teagasc (the Agriculture and Food Development Authority of Ireland) and Vita.

Open Access This article is distributed under the terms of the Creative Commons Attribution 4.0 International License (http:// creativecommons.org/licenses/by/4.0/), which permits unrestricted use, distribution, and reproduction in any medium, provided you give appropriate credit to the original author(s) and the source, provide a link to the Creative Commons license, and indicate if changes were made.

\section{References}

Abush, T., M. Githiri, J. Derera, and T. Debele. 2011. Subsistence farmers' experience and perception about the soil, and fertilizer use in Western Ethiopia. Ethiopian Journal of Applied Science and Technology 2(2): 61-74.

Agajie, T., G. Woldegiorgis, W. Kaguongo, B. Lemaga, and D. Nigussie. 2013. Adoption and impact of potato production technologies in Oromia and Amhara Regions. Paper presented at the national workshop on seed potato tuber production and dissemination, 12-14 March 2012, Bahir Dar, Ethiopia.

APHRD (Animal and Plant Health Regulatory Directorate). 2009. Crop variety register, Issue No. 12, June, 2009, Ministry of Agriculture and Rural Development, Addis Ababa, Ethiopia.

Baye, B., and G. Woldegiorgis. 2013. Potato research and development in Ethiopia: Achievements and trends. Paper presented at the national workshop on seed potato tuber production and dissemination, 12-14 March 2012, Bahir Dar, Ethiopia.

Belete G. 2006. Impact of male out-migration on rural women's livelihood: the case of Chencha Woreda, South Ethiopia, MSc thesis, Addis Ababa University, Addis Ababa, Ethiopia.

Beliyu, L., T. Tefera, and E. Lahiff. 2013. Determinants of adoption of improved potato varieties in Welmera Woreda. Paper presented at the national workshop on seed potato tuber production and dissemination, 12-14 March 2012, Bahir Dar, Ethiopia.

Berga, L., and G. Woldegiorgis. 1994. Prospects of seed potato production in Ethiopia. Paper presented at the second national horticultural workshop of Ethiopia, Addis Ababa, Institute of Agricultural Research and FAO.

Bezabih, E., and M. Nigussie. 2011. Potato value chain analysis and development in Ethiopia: case of Tigray and SNNP Regions. Addis Ababa Ethiopia: International Potato Centre (CIP-Ethiopia).

CSA (Central Statistics Agency). 2011a. Agricultural sample survey 2010 / 2011 (2003 E.C.), volume III, report on farm management practices (private peasant holdings, meher season), May, 2011, Addis Ababa.

CSA (Central Statistics Agency). 2011a. Statistical abstract 2011. Addis Ababa: CSA.
CSA (Central Statistics Agency). 2012. Agricultural Sample Survey 2011/2012. Volume-I. Report on area and production of major crops (private sector meher season). CSA, Addis Ababa.

CSA (Central Statistics Agency) \& World Bank. 2013. Ethiopia rural socioeconomic survey report. http://siteresources.worldbank.org/ INTLSMS/Resources. Accessed 20 March 2015.

Daniel, Z., and D.F. Larson. 2010. Incomplete markets and fertilizer use: evidence from Ethiopia, The World Bank, Development Research Group, Agriculture and Rural Development Team, Policy Research Working Paper 5235.

Endale, K. 2011. Fertilizer consumption and agricultural productivity in Ethiopia, the Ethiopian Development Research Institute (EDRI), Working Paper 003, Addis Ababa, Ethiopia.

Gebremedhin, W., G. Endale, and B. Lemaga. 2008. Potato variety development. In Root and tuber crops: The untapped resources, ed. W. Gebremedhin, G. Endale, and B. Lemaga, 15-32. Addis Ababa: Ethiopian Institute of Agricultural Research.

Gumataw, K.A., B. Jos, P. Stefano, and O. Omta. 2013. Adoption of improved potato varieties in Ethiopia: The role of agricultural knowledge and innovation system and smallholder farmers' quality assessment. Agricultural Systems 122: 22-32.

Hirpa, A., M.P.M. Meuwissen, A. Tesfaye, W.J.M. Lommen, A. Oude Lansink, A. Tsegaye, and P.C. Struik. 2010. Analysis of seed potato systems in Ethiopia. American Journal of Potato Research 87: 537552.

IFDC (International Fertilizer Development Centre). 2012. Ethiopia fertilizer assessment. http://www.ifdc.org/r-d/research/ethiopiafertilizer-assessment. Accessed 15 March 2015.

Josephson, A.L., R. Jacob, and R.J.G.M. Florax. 2014. How does population density influence agricultural intensification and productivity? Evidence from Ethiopia. Food Policy 48: 142-152.

Mesfin, M., G. Girmay, and F. Woldeyes. 2014. Enhancing household food security through Irish potato production in Gamo Highlands of Southern Ethiopia. Scholarly Journal of Agricultural Science 4: $410-419$.

Nascimento, L.C., G. Pio-Ribeiro, L. Willadino, and G.P. Andrade. 2003. Stock indexing and potato virus $\mathrm{Y}$ elimination from potato plants cultured in vitro. Scientia Agricola 60: 525-530.

Schulte-Geldermann, E. 2013. Tackling low potato yields in Eastern Africa: an overview of constraints and potential Strategies. Paper presented at the national workshop on seed potato tuber production and dissemination, 12-14 March 2012, Bahir Dar, Ethiopia.

Teklemariam T. M. 2014. The impact of international potato centre's nutrition project on smallholder farmers' income and adoption of improved potato varieties: Tigray region, Northern Ethiopia, MSc Thesis, Mekelle University College of Business and Economics.

Tewodros, A., P.C. Struik, and A. Hirpa. 2014. Characterization of seed potato (Solanum tuberosum L.) storage, pre-planting treatment and marketing systems in Ethiopia: The case of West-Arsi Zone. African Journal of Agricultural Research 9: 1218-1226. 